\author{
Ni Wayan Shintya Dharmayatri ${ }^{1}$ \\ Fakultas Ekonomi dan Bisnis \\ Universitas Udayana, Indonesia
}

\author{
I Dewa Nyoman Wiratmaja ${ }^{2}$ \\ Fakultas Ekonomi dan Bisnis \\ Universitas Udayana, Indonesia
}

\begin{abstract}
Surel : shintyadharma12@gmail.com
ABSTRAK

Tujuan penelitian ini adalah untuk mengetahui pengaruh return on asstes, leverage dan ukuran perusahaan pada tax avoidance. Penelitian ini dilakukan pada perusahaan sektor pertambangan yang listing di BEI tahun 2017-2019. Metode penentuan sampel yang digunakan adalah menggunakan purposive sampling. Jumlah perusahaan yang memenuhi kriteria adalah 11 perusahaan dengan jumlah 33 amatan. Pengumpulan data dilakukan dengan metode observasi non partisipan. Teknik Analisis data yang digunakan yaitu analisis regresi linear berganda. Berdasarkan hasil penelitian, ditemukan bahwa return on assets dan ukuran perusahaan memiliki pengaruh negatif pada tax avoidance, sedangkan leverage berpengaruh positif pada tax avoidance.
\end{abstract}

Kata Kunci: Tax Avoidance; Return On Assets; Leverage; Ukuran Perusahaan.

\section{Return On Assets, Leverage, Company Size and Tax Avoidance}

\section{ABSTRACT}

The purpose of this study was to determine the effect of return on assessment, leverage and company size on tax avoidance. This research was conducted on mining sector companies listed on the IDX in 20172019. The sampling method used was purposive sampling. The number of companies that met the criteria was 11 companies with 33 observations. Data collection was carried out by non-participant observation method. The data analysis technique used is multiple linear regression analysis. Based on the research results, it was found that return on assets and company size have a negative effect on tax avoidance, while leverage has a positive effect on tax avoidance.

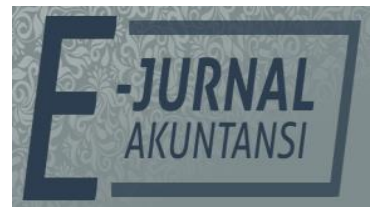

e-ISSN 2302-8556

Vol. 31 No. 9

Denpasar, September 2021 Hal. 2301-2311

DOI:

10.24843/EJA.2021.v31.i09.p12

PENGUTIPAN:

Dharmayatri, N.W.S., \&

Wiratmaja, I.D.N. (2021).

Return On Assets, Leverage,

Company Size dan Tax Avoidance. E-Jurnal Akuntansi,

31(9), 2301-2311

RIWAYAT ARTIKEL:

Artikel Masuk:

25 Februari 2021

Artikel Diterima:

16 Juni 2021

Keywords: Tax Avoidance; Return On Assets; Leverage; Company Size.

Artikel dapat diakses : https://ojs.unud.ac.id/index.php/Akuntansi/index 


\section{PENDAHULUAN}

Pajak menurut Undang-Undang Nomor 16 tahun 2009 tentang Ketentuan Umum dan Tata Cara Perpajakan pada Pasal 1 ayat 1 Pajak adalah kontribusi wajib kepada negara yang terutang oleh orang pribadi atau badan yang bersifat memaksa berdasarkan Undang-Undang, dengan tidak mendapatkan imbalan secara langsung dan digunakan untuk keperluan negara bagi sebesar-besarnya kemakmuran rakyat. Pajak merupakan sektor yang memegang peranan penting dalam perekonomian, karena dalam pos penerimaan Anggaran Pendapatan dan Belanja Negara (APBN) sumbangan pajak memiliki porsi yang lebih besar dibandingkan dengan sumber penerimaan lain (Dewi \& Noviari, 2017). Pemerintah terus berupaya untuk mengoptimalkan sistem perpajakan dalam rangka mewujudkan kesejahterakan seluruh rakyat Indonesia. (Darmayanti \& Lely Aryani Merkusiawati, 2019). Dimulai dari reformasi perpajakan pada tahun 1983, pemerintah secara menyeluruh mengubah sistem pemungutan pajak dari official assessment system menjadi self-assessment system (Wirawan \& Sukartha, 2018).

Usaha yang dilakukan pemerintah untuk mengoptimalkan pendapatan pajak bukan tanpa kendala. Seiring dengan pemerintah melakukan perbaikan sistem perpajakan, terdapat perbedaan kepentingan antara pemerintah dan perusahaan. Pajak bagi perusahaan merupakan beban yang dapat mengurangi laba perusahaan sehingga perusahaan mencari berbagai cara untuk mengurangi beban pajak tersebut (Wijayanti \& Merkusiwati, 2017). Berdasarkan teori agensi adanya perbedaan kepentingan antara pemerintah dan wajib pajak yang menyebabkan terjadinya praktik tax avoidance yang dilakukan wajib pajak untuk mengurangi beban pajak tersebut. Tax avoidance adalah suatu tindakan untuk mengurangi beban pajak dengan hati-hati mengatur sedemikian rupa untuk mengambil keuntungan dari celah-celah dalam ketentuan pajak. Persoalan tax avoidance terlihat rumit sekaligus unik karena disatu sisi tax avoidance tidak melanggar hukum, akan tetapi tax avoidance tidak diinginkan oleh pemerintah.

Tindakan tax avoidance yang dilakukan perusahaan dipandang sebagai tindakan yang merugikan masyarakat. Masyarakat akan memandang bahwa perusahaan seharusnya berpartisipasi dalam memajukan kesejahteraan masyarakat melalui pajak, sedangkan yang terjadi di sisi lain perusahaan melihat bahwa tindakan tax avoidance dapat memberikan keuntungan ekonomis kepada perusahaan. Perusahaan yang melakukan tax avoidance bukan enggan ikut berkontribusi melainkan mengatur jumlah pajak yang akan di bayarkan agar berkurang dari jumlah yang seharusnya. Tax avoidance kaitannya dengan penerimaan pajak karena penghindaran pajak yang dilakukan perusahaan akan berdampak terhadap besar kecilnya pemungutan pajak yang menimbulkan pembangunan nasional dan kesejahteraan tidak merata. Berdasarkan data yang dipublikasikan oleh Kementerian Keuangan Republik Indonesia, besarnya target dan realisasi penerimaan pajak pada tahun 2016-2019, disajikan dalam Tabel 1, berikut.

Berdasarkan Tabel 1, presentasi realisasi penerimaan negara yang berasal dari pajak tahun 2016-2018 mengalami peningkatan namun tahun pada 2019 mengalami penurunan sehingga belum mencapai target penerimaan pajak yang ditentukan. Realiasi penerimaan pajak yang belum maksimal menimbulkan 
pertanyaan apakah pemungutan pajak belum dilakukan secara maksimal atau Wajib Pajak melakukan praktik penghindaran pajak dalam mengurangi beban pajaknya.

Tabel 1. Target dan Realisasi Penerimaan Pajak Tahun 2016-2019

\begin{tabular}{cccc}
\hline Tahun & $\begin{array}{c}\text { Target Penerimaan Pajak } \\
\text { (Trilliun Rupiah) }\end{array}$ & $\begin{array}{c}\text { Realisasi } \\
\text { Penerimaan Pajak } \\
\text { (Trilliun Rupiah) }\end{array}$ & $\begin{array}{c}\text { Persentase Realisasi } \\
\text { Penerimaan Pajak }\end{array}$ \\
\hline 2016 & 1,539 & 1,285 & 83,5 \\
2017 & 1,473 & 1,340 & 91,0 \\
2018 & 1,424 & 1,315 & 92,4 \\
2019 & 1,577 & 1,136 & 72,0 \\
\hline
\end{tabular}

Sumber: Kementrian Keuangan Republik Indonesia, 2019

Salah satu sektor yang kerap melakukan tindakan penghindaran pajak adalah sektor pertambangan. Sektor pertambangan merupakan sektor usaha yang bergerak pada usaha penggalian, pengambilan dari endapan bahan-bahan galian yang berharga serta nilai ekonomis berasal dari dalam kulit bumi, secara mekanis ataupun manual, di permukaan bumi, bawah permukaan bumi serta air. Sektor pertambangan di Indonesia merupakan salah satu sektor strategis yang menjadi andalan, sayangnya pengelolaan sektor ini belum cukup transparan sehingga potensi bagi negara belum cukup optimal. Kementerian Keuangan Republik Indonesia menyoroti masih rendahnya tingkat kepatuhan wajib pajak di bidang pertambangan mineral dan batu bara (minerba) dan minyak dan gas bumi (migas). Pada tahun 2015, misalnya, pengusaha minerba yang melaporkan Surat Pemberitahuan Tahunan tercatat sebanyak 2.557, sedangkan yang tidak melaporkan mencapai 3.624. Ini menunjukkan bahwa tingkat kepatuhan pajak perusahaan pertambangan terbilang rendah, sehingga mengindikasikan adanya keinginan perusahaan untuk melakukan tidakan tax avoidance.

Terdapat beberapa faktor yang mempengaruhi suatu perusahaan melakukan kewajiban perpajakannya seperti Return on asset. Return on asset (ROA) merupakan salah satu rasio yang dapat mencerminkan profitabilitas suatu perusahaan. Semakin tinggi return on asset berarti semakin tinggi laba perusahaan. Semakin tinggi nilai return on assets maka akan semakin baik kinerja perusahaan tersebut(Arianandini \& Ramantha, (2018) Laba perusahaan merupakan dasar dari pengenaan pajak. Perusahaan yang memiliki Return on asset tinggi akan melakukan upaya yang bertujuan untuk menghasilkan pajak optimal dengan meminimalkan beban pajaknya, sehingga perusahaan cenderung melakukan tax avoidance (Nugrahitha \& Suprasto, 2018).

Kebijakan pendanaan yang diambil perusahaan dapat mengindikasi suatu perusahaan melakukan penghindaran pajak. Kebijakan pendanaan yang mengindikasikan perusahaan melakukan penghindaran pajak yaitu kebijakan leverage. Leverage adalah suatu perbandingan yang mencerminkan besarnya utang yang digunakan untuk pembiayaan oleh perusahaan dalam menjalankan aktivitas operasinya(Praditasari \& Setiawan, 2017). Semakin tinggi tingkat utang maka diindikasikan semakin tinggi pula perusahaan melakukan penghindaran pajak. Tujuan dilakukannya penghindaran pajak adalah dana yang harus digunakan untuk membayar pajak perusahaan, oleh perusahaan digunakan untuk membayar 
utang itu sendiri.

Ukuran perusahaan dianggap mampu mempengaruhi cara sebuah perusahaan dalam memenuhi kewajiban pajaknya dan merupakan faktor yang dapat menyebabkan terjadinya tax avoidance. Kurniasih \& Sari, (2013) Ukuran perusahaan menunjukkan kestabilan dan kemampuan perusahaan untuk melakukan aktivitas ekonominya. Perusahaan yang memiliki aset yang besar akan cenderung menghasilkan lebih banyak laba dibandingkan dengan perusahaan dengan aset yang kecil. Laba yang besar dan stabil akan cenderung mendorong perusahaan untuk melakukan praktik penghindaran pajak (tax avoidance) karena laba yang besar akan menyebabkan beban pajak yang besar pula (Dewinta \& Setiawan, 2016).

Penelitian tentang Tax avoidance semakin menarik untuk di teliti, karena penelitian mengenai faktor-faktor yang mempengaruhi tax avoidance ini sudah banyak di teliti dan hasilnya berbeda-beda. Penelitian ini penting untuk membuktikan kembali terkait pengaruh Return on assets, Leverage, dan Ukuran Perusahaan pada Tax avoidance. Penelitian ini mereplikasi penelitian (Handayani, 2018) yang meneliti pengaruh Return on assets, Leverage, dan Ukuran Perusahaan terhadap Tax avoidance Pada Perusahaan Perbankan yang Listing di BEI Periode 2012-2015. Untuk membedakan penelitian ini dengan penelitian sebelumnya, peneliti menggunakan laporan tahunan (annual report) perusahaan pada periode 2017-2019 dan meneliti pada perusahaan pertambangan.

Berdasarkan penjelasan yang telah di uraikan di atas, maka diambil judul penelitian "Pengaruh Return on assets, leverage dan Ukuran perusahaan Terhadap Tax avoidance (tudi Empiris Pada Perusahaan Pertambangan yang Terdaftar di Bursa Efek Indonesia Periode 2017-2019)".

\section{METODE PENELITIAN}

Peneitian ini menggunakan pendekatan kuantitatif statistik, dengan tujuan untuk mengetahui pengaruh variabel bebas (independent) yaitu return on assets, leverage dan ukuran perusahaan pada variabel terkat (dependent) yaitu tax avoidance. Objek penelitian adalah sasaran ilmiah untuk mendapatkan data keuangan dengan tujuan dan kegunaan tertentu tentang sesuatu hal objektif, valid, dan reliable tentang suatu hal (variabel tertentu) (Sugiyono, 2017:13). Objek yang digunakan pada penelitian ini adalah Return on assets $\left(\mathrm{X}_{1}\right)$, Leverage $\left(\mathrm{X}_{2}\right)$, Ukuran Perusahaan $\left(\mathrm{X}_{3}\right)$ dan tax avoidance $(\mathrm{Y})$ pada perusahaan pertambangan yang terdaftar di bursa efek Indonesia periode 2017-2019. Penelitian ini dilakukan di perusahaan pertambangan yang terdaftar d Bursa Efek Indonesia Periode 2017-2019 dengan mengakses data perusahaan berupa informasi laporan keuangan pada situs resminya di www.idx.co.id.

Analisis regresi linier berganda dapat menunjukkan arah hubungan antar variabel, digunakan untuk memecahkan rumusan masalah yang ada, atau apakah memiliki hubungan positif atau negative. Analisis linier berganda adalah pengujian yang dilakukan untuk mengetahui ada tidaknya pengaruh Profitabilitas $\left(X_{1}\right)$, Leverage $\left(X_{2}\right)$, dan Ukuran Perusahaan $\left(X_{3}\right)$ terhadap Tax avoidance $(Y)$. Adapun model regresi linier berganda dirumuskan sebagai berikut.

$Y=\alpha+\beta_{1} X_{1}+\beta_{2} X_{2}+\beta_{3} X_{3}+\varepsilon$

Keterangan: 


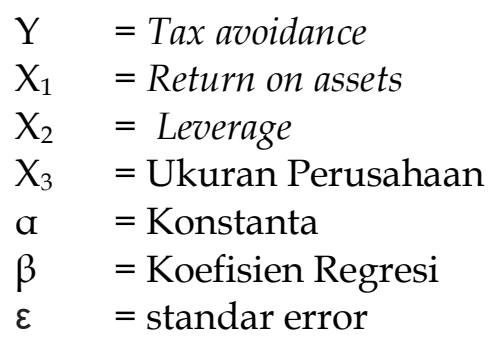

\section{HASIL DAN PEMBAHASAN}

Uji regresi linier berganda digunakan untuk mengetahui dan memperoleh gambaran mengenai pengaruh variabel-variabel independen yaitu Return on asset $\left(X_{1}\right)$, Leverage $\left(X_{2}\right)$ Dan Ukuran Perusahaan $\left(X_{3}\right)$ Pada Variabel Dependen yaitu Tax avoidance $(\mathrm{Y})$. Hasil analisis regresi linier berganda dapat dilihat pada Tabel 2, berikut.

Tabel 2. Hasil Analisis Regresi Linier Berganda

\begin{tabular}{|c|c|c|c|c|c|}
\hline \multirow[b]{2}{*}{ Model } & \multicolumn{2}{|c|}{$\begin{array}{l}\text { Unstandardized } \\
\text { Coefficients }\end{array}$} & \multirow{2}{*}{$\begin{array}{c}\text { Standardized } \\
\text { Coefficients }\end{array}$} & \multirow[b]{2}{*}{$\mathrm{t}$} & \multirow[b]{2}{*}{ Sig. } \\
\hline & B & Std. Error & & & \\
\hline (Constant) & $-0,255$ & 0,262 & & $-0,972$ & 0,339 \\
\hline Return on asset & $-0,034$ & 0,012 & $-0,295$ & $-2,801$ & 0,009 \\
\hline Leverage & 0,025 & 0,004 & 0,711 & 6,830 & 0,000 \\
\hline $\begin{array}{l}\text { Ukuran } \\
\text { Perusahaan }\end{array}$ & $-0,041$ & 0,019 & $-0,225$ & $-2,134$ & $-0,041$ \\
\hline $\mathrm{R}$ & 0,828 & & & & \\
\hline R Square & 0,686 & & & & \\
\hline Adjusted R Square & 0,654 & & & & \\
\hline F hitung & 21,133 & & & & \\
\hline Signifikan F & 0,000 & & & & \\
\hline
\end{tabular}

Sumber: Data Penelitian, 2020

Berdasarkan Tabel 2, menunjukkan hasil analisis regresi, sebagai berikut.

$$
\mathrm{Y}=-0,255-0,034 \mathrm{X}_{1}+0,025 \mathrm{X}_{2}-0,041 \mathrm{X}_{3}
$$

Nilai konstanta sebesar $-0,255$, artinya jika variabel return on asset, leverage dan ukuran perusahaan bernilai 0 maka tax avoidance sebesar $-0,255$. Nilai koefisien variabel return on asset $\left(\mathrm{X}_{1}\right)$ bernilai negatif 0,034 , artinya apabila return on asset $\left(\mathrm{x}_{1}\right)$ mengalami peningkatan satu satuan dengan asumsi variabel leverage dan ukuran perusahaan dianggap tetap maka tax avoidance akan menurun sebesar 0,034 . Nilai koefisien variabel leverage $\left(\mathrm{X}_{2}\right)$ bernilai positif 0,025 , artinya apabila leverage $\left(\mathrm{X}_{2}\right)$ mengalami peningkatan satu satuan dengan asumsi variabel return on asset dan ukuran perusahaan dianggap tetap maka tax avoidance akan meningkat sebesar 0,025. Nilai koefisien variabel ukuran perusahaan $\left(X_{3}\right)$ bernilai negatif 0,041 , artinya apabila ukuran perusahaan $\left(X_{3}\right)$ mengalami peningkatan satu satuan dengan asumsi variabel return on asset dan leverage dianggap tetap maka tax avoidance akan menurun sebesar 0,041.

Berdasarkan Tabel 2, besarnya pengaruh variabel bebas terhadap variabel terikat yang ditunjukkan oleh koefisien determinasi yang telah disesuaikan (Adjused $R^{2}$ ) sebesar 0,654. Ini berarti bahwa sebesar 65,4 persen variasi tax avoidance dipengaruhi oleh variasi return on asset, leverage, ukuran perusahaan, 
sedangkan sisanya sebesar 34,6 persen dijelaskan oleh faktor lain yang tidak dimasukkan ke dalam model penelitian.

Uji kelayakan model (Uji F) bertujuan untuk menguji apakah model yang digunakan dalam penelitian ini layak atau tidak untuk digunakan sebagai alat analisis dalam menguji pengaruh variabel independen pada variabel dependennya. Berdasarkan hasil analisis diperoleh nilai Signifikansi uji F yakni $0,000<0,05$. Hasil ini mempunyai arti bahwa ada pengaruh Signifikan secara simultan antara variabel bebas return on asset, leverage, ukuran perusahaan terhadap varaibel terikat yaitu tax avoidance. Uji ini digunakan untuk menguji Signifikan masing-masing koefisien regresi sehingga diketahui apakah hubungan Variabel Independen berpengaruh secara parsial terhadap Variabel Dependen adalah memang nyata terjadi (Signifikan) atau hanya diperoleh secara kebetulan.

Tabel 3. Hasil Uji t

\begin{tabular}{llrrrrr}
\hline & \multicolumn{2}{c}{$\begin{array}{l}\text { Unstandardized } \\
\text { Coefficients }\end{array}$} & \multicolumn{2}{c}{$\begin{array}{c}\text { Standardized } \\
\text { Coefficients }\end{array}$} & & \\
\cline { 2 - 4 } Model & \multicolumn{1}{c}{ B } & Std. Error & \multicolumn{1}{c}{ Beta } & \multicolumn{1}{c}{ - } & \multicolumn{1}{c}{ Sig. } \\
\hline $1 \quad$ (Constant) & $-0,255$ & 0,262 & & $-0,972$ & 0,339 \\
$\quad$ Return on asset & $-0,034$ & 0,012 & $-0,295$ & $-2,801$ & 0,009 \\
$\quad$ Leverage & 0,025 & 0,004 & 0,711 & 6,830 & 0,000 \\
$\quad$ Ukuran & $-0,041$ & 0,019 & $-0,225$ & $-2,134$ & 0,041 \\
$\quad$ Perusahaan & & & & &
\end{tabular}

a. Dependent Variable: Tax avoidance

Sumber: Data Penelitian, 2020

Pengaruh variabel return on assets, leverage dan ukuran perusahaan terdadap tax avoidance di uji menggunakan Uji t. Kriteria pengujian untuk menjelaskan interpretasi pengaruh antar masing-masing variabel yakni apabila nilai Signifikansi $<0,05$ maka $\mathrm{H}_{0}$ ditolak dan $\mathrm{H}_{1}$ diterima. Sebaliknya, jika nilai Signifikansi $>0,05$ maka $\mathrm{H}_{0}$ diterima dan $\mathrm{H}_{1}$ ditolak.

Berdasarkan hasil analisis diperoleh nilai Signifikansi sebesar 0,009 dengan nilai koefisien regresi sebesar $-0,034$ dan nilai $t$ hitung $>t$ tabel $(2,801>1,6973)$, Hasil ini mempunyai arti bahwa return on asset berpengaruh negatif terhadap tax avoidance. Hasil pengujian hipotesis menunjukkan bahwa, return on assets berpengaruh negatif pada tax avoidance perusahaan pertambangan di Bursa Efek Indonesia. Temuan ini memberikan bukti bahwa semakin meningkat return on asset akan semakin menurunkan tax avoidance, sebaliknya jika return on asset semakin menurun, maka tax avoidance akan semakin meningkat.

Berdasarkan hasil analisis diperoleh nilai Signifikansi sebesar 0,000 dengan nilai koefisien regresi sebesar 0,025 dan nilai $t$ hitung $>t$ tabel $(6,830>1,6973)$, Hasil ini mempunyai arti bahwa leverage berpengaruh positif terhadap tax avoidance. Pengaruh Ukuran Perusahaan terhadap Tax avoidance. Ukuran perusahaan berpengaruh terhadap tax avoidance. Berdasarkan hasil analisis diperoleh nilai Signifikansi sebesar 0,041 dengan nilai koefisien regresi sebesar 0,041 dan nilai $t$ hitung $>t$ tabel $(2,134>1,6973)$, Hasil ini mempunyai arti bahwa ukuran perusahaan berpengaruh negatif terhadap tax avoidance.

Hasil penelitian ini mendukung penelitan Annisa, (2017) dan Hendrani et al., (2020) yang menyatakan bahwa return on asstes berpengaruh negatif pada tax avoidance. Perusahaan dengan return on assets tinggi akan memiliki kemampuan 
kuangan untuk melakukan pembayaran pajak tanpa melakukan penghindaran pajak. Penelitian ini tidak sejalan dengan penelitian(Aminah et al., 2017) dan Irianto, (2017) yang menyatakan bahwa return on assets berpengaruh positif pada tax avoidance karena menggunakan sektor manufaktur yang terdaftar di Bursa Efek Indonesia.

Menurut Jensen \& Meckling, (1976) teori keagenan adalah hubungan antara satu pihak atau lebih principal mempekerjakan orang lain (agent) untuk memberikan suatu jasa kemudian mendelegasikan wewenang pengembalian keputusan pada agen tersebut. Principal berharap agar manajemen selaku agen menghasilkan return on assets yang tinggi sebagai bentuk kemakmuran. Manajemen selaku agen menginginkan peningkatan kompensasi melalui keuntungan yang tinggi, sedangkan pemengang saham principal ingin menekan biaya pajak. Meskipun penelitian ini tidak mendukung teori keagenan, akan tetapi hasil penelitian ini mendukung teori kepatuhan Tyler,(1986) menyatakan bahwa kepatuhan adalah taat kepada perintah atau aturan dan kepatuhan berarti sifat patuh, taat, tunduk pada ajaran atau peraturan. Perusahaan meyakini dengan memiliki retrun on assets yang tinggi perusahaan mampu membayar pajak sesuai dengan aturan perundangan-undangan yang berlaku tanpa harus melakukan kegiatan penghindaran pajak. Perusahaan yang memiliki perencanaan pajak yang baik maka akan memperoleh pajak yang optimal, hal tersebut berakibat kecederungan perusahaan melakukan penghindaran pajak akan menurun (Cahya Dewanti \& Sujana, 2019).

Temuan penelitian ini menunjukkan bahwa perusahaan dengan return on assets tinggi cenderung tidak melakukan tax avoidance dan sebalikya. Temuan ini mengindikasikan bahwa tax avoidance cenderung terjadi pada perusahaan dengan return on assets rendah dikarenakan perusahaan tersebut tidak memiliki sumber daya difinansial yang cukup untuk memenuhi kewajiban pajaknya. Untuk fiskus agar lebih fokus melaksanakan pengawasan secara lebih intensif pada perusahaan dengan return on assets rendah.

Hasil pengujian hipotesis menunjukkan bahwa, leverage berpengaruh positif pada tax avoidance perusahaan pertambangan di Bursa Efek Indonesia. Temuan ini memberikan bukti bahwa semakin meningkat leverage akan semakin meningkatkan tax avoidance, sebaliknya jika leverage semakin menurun, maka tax avoidance akan semakin menurun. Hasil penelitian ini mendukung penelitian Fauzan et al., (2019) dan Alfina et al., (2018) yang menyatakan bahwa leverage berpengaruh positif pada tax avoidance. Alfina et al., (2018) menyatakan bahwa tingginya hutang suatu perusahaan akan menimbulkan beban bagi perusahaan yaitu beban bunga.

Teori trade off berasumsi bahwa perusahaan akan menggunakan hutang sampai tingkat tertentu untuk memaksimalkan nilai perusahaan dengan memanfaatkan pajak akibat penggunaan hutang. Pendanaan keuangan oleh perusahaan yang berasal dari penggunaan hutang dapat member manfaat sebagai pengurang beban pajak karena penggunaan hutang menimbulkan beban bunga. Tingkat beban bunga yang sangat tinggi pada suatu perusahaan dapat mengurangi beban pajak perusahaan, sehingga perusahaan yang memiliki beban pajak yang tinggi akan memilih berutang kepada pihak lain dengan modal sendiri 
untuk meminimalkan beban pajak. Hal ini menunjukkan bahwa perusahaan yang memiliki leverage tinggi cenderung melakukan penghindaran pajak.

Temuan penelitian ini menunjukkan bahwa perusahaan dengan leverage tinggi cenderung melakukan tax avoidance dan sebalikya. Temuan ini mengindikasikan bahwa tax avoidance cenderung terjadi pada perusahaan dengan leverage tinggi karena hutang suatu perusahaan akan menimbulkan beban bunga yang mengurangi beban pajak. Untuk itu fiskus agar lebih fokus melaksanakan pengawasan secara lebih intensif pada perusahaan dengan leverage tinggi.

Pengaruh Ukuran Perusahaan terhadap Tax avoidance

Hasil pengujian hipotesis menunjukkan bahwa, ukuran perusahaan berpengaruh negatif pada tax avoidance perusahaan pertambangan di Bursa Efek Indonesia. Temuan ini memberikan bukti bahwa semakin besar ukuran perusahaan akan semakin menurunkan tax avoidance, sebaliknya jika ukuran perusahaan semakin kecil, maka tax avoidance akan semakin meningkat. Hasil penelitian ini mendukung penelitan Solihin et al., (2020) dan Dewi \& Noviari, (2017) yang menyatakan bahwa ukuran perusahaan berpengaruh negatif pada tax avoidance. Dewi \& Noviari, (2017) menyatakan perusahaan yang dikelompokkan ke dalam ukuran yang besar (memiliki aset yang besar) dapat memengaruhi secara Signifikan menurunnya praktik penghindaran pajak yang dapat terjadi dalam di perusahaan.

Menurut Jensen \& Meckling, (1976) teori keagenan adalah hubungan antara satu pihak atau lebih (principal) mempekerjakan orang lain (agent) untuk memberikan suatu jasa kemudian mendelegasikan wewenang pengembalian keputusan pada agen tersebut. Hubungan dengan agent dan principal berkaitan ketika principal telah mencapai kemakmuran manajemen selaku agent melakukan tax avoidance cenderung menurun. Hasil penelitian ini juga sejalan dengan teori kepatuhan. Tyler, (1986) enyatakan bahwa kepatuhan adalah taat kepada perintah atau aturan dan kepatuhan berarti sifat patuh, taat, tunduk pada ajaran atau peraturan. Perusahaan dengan ukuran yang besar akan menjadi sorotan oleh pemerintah (regulator) sehingga perusahaan besar menggunakan sumber dayanya untuk melakukan perencanaan pajak yang baik dan menataati aturan perpajakan yang berlaku (Kusufiyah et al., 2019). Temuan penelitian ini menunjukkan bahwa perusahaan dengan ukuran perusahaan yang tinggi cenderung tidak melakukan tax avoidance dan sebalikya. Temuan ini mengindikasikan bahwa tax avoidance cenderung terjadi pada perusahaan dengan ukuran perusahaan yang rendah. Untuk itu fiskus agar lebih fokus melaksanakan pengawasan secara lebih intensif pada perusahaan dengan ukuran perusahaan rendah.

Implikasi Teoritis. Penelitian ini menghasilkan simpulan mengenai bagaimana pengaruh return on assets, leverage, dan ukuran perusahaan pada tax avoidance. Hasil dari penelitian ini dapat memberikan wawasan dalam mendeteksi adanya praktik tax avoidance dalam sektor pertambangan. Penelitian ini juga membuktikan teori kepatuhan yang menjelaskan suatu kondisi dimana seseorang taat terhadap aturan, dimana perusahaan meyakini membayar pajak sesuai dengan aturan perundangan-undangan yang berlaku tanpa harus melakukan kegiatan penghindaran pajak.

Implikasi Praktis. Penelitian ini diharapkan akan memberikan kontribusi 
positif bagi semua pihak khususnya pihak pemerintah dan perusahaan. Hasil penelitian ini diharapkan memberi kontribusi implikasi kebijakan kepada pihak manajemen perusahaan dan pemerintah. Manajemen perusahaan sebaiknya memerhatikan lebih seksama terkait kebijakan-kebijakan yang akan diambil perusahaan. Tindakan pajak tax avoidance dilakukan manajemen untuk mengurangi beban pajaknya. Namun tentunya manajemen perusahaan harus tetap bertindak sesuai dengan peraturan yang berlaku sehingga tidak menimbulkan kerugian pada perusahaan. Pemerintah melalui Direktorat Jenderal Pajak diharapkan terus memantau kebijakan-kebijakan yang diambil perusahaan agar tidak melanggar hukum yang berlaku.

\section{SIMPULAN}

Berdasarkan hasil analisis penelitian dan hasil pembahasan pada bab sebelumnya maka simpulan dari penelitian ini adalah sebagai berikut: 1. Return on asset berpengaruh negatif terhadap tax avoidance. Hal ini berarti semakin meningkat return on asset semakin menurunkan tax avoidance. 2. Leverage berpengaruh positif terhadap tax avoidance. Hal ini berarti semakin meningkat leverage akan semakin meningkatkan tax avoidance. 3. Ukuran perusahaan berpengaruh negatif terhadap tax avoidance. Hal ini berarti semakin besar ukuran perusahaan akan semakin menurunkan tax avoidance. Berdasarkan hasil analisis pembahasan adapun saransaran yang dapat diberikan melalui hasil penelitian ini agar mendapatkan hasil yang lebih baik, yaitu: Penelitian ini hanya menggunakan perusahaan pada sektor pertambangan, ini mengakibatkan keterbatasan data yang ada sehingga hasil dari penelitian ini kurang tepat jika digeneralisasi di semua sektor. Jadi untuk peneliti selanjutnya diharapkan dapat menggunakan sektor lainnya seperti aneka industri, keuangan, dan manufaktur. Hasil uji koefisien determinasi (R2) dalam penelitian ini sebesar 65,4 persen yang sebesar 34,6 persen variasi dalam variabel tax avoidance dipengaruhi oleh variabel lain yang tidak diteliti. Untuk itu kepada peneliti selanjutnya dapat disarankan untuk mengembangkan variabel.

\section{REFERENSI}

Alfina, I. T., Nurlaela, S., \& Wijayanti, A. (2018). The Influence of Profitability, Leverage, Independent Commissioner, and Company Size to Tax avoidance. The 2nd International Conference on Technology, Education, and Social Science 2018, 2018(10), 102-106. Retrieved from https://ejurnal.unisri.ac.id/index.php/proictss/article/view/2201

Aminah, Chairina, \& Sari, Y. Y. (2017). The Influence of Company Size, Fixed Asset Intensity, Leverage, Profitability, and Political Connection To Tax avoidance. AFEBI Accounting Review (AAR), 02(02), 30-43.

Annisa. (2017). Pengaruh Return on asset, Leverage, Ukuran Perusahaan Dan Koneksi Politik Terhadap Penghindaran Pajak. JOMFekom, 4(1), 1960-1970.

Arianandini, Putu Winning \& Ramantha, I. W. (2018). Pengaruh Profitabilitas, Leverage, dan Kepemilikan Institusional Pada Tax avoidance. E-Jurnal Akuntansi, 22, 2088-2116.

Cahya Dewanti, I. G. A. D., \& Sujana, I. K. (2019). Pengaruh Ukuran Perusahaan, Corporate Social Responsibility, Profitabilitas dan Leverage pada Tax 
avoidance. E-Jurnal Akuntansi,

https://doi.org/10.24843/eja.2019.v28.i01.p15

Darmayanti, P. P. B., \& Lely Aryani Merkusiawati, N. K. (2019). Pengaruh Ukuran Perusahaan, Profitabilitas, Koneksi Politik dan Pengungkapan Corporate Social Responsibility Pada Tax avoidance. E-Jurnal Akuntansi, 26, 1992. https://doi.org/10.24843/eja.2019.v26.i03.p12

Dewi, N. L. P. P., \& Noviari, N. (2017). Pengaruh Ukuran Perusahaan, Leverage, Profitabilitas Dan Corporate Social Responsibility Terhadap Penghindaran Pajak (Tax avoidance). E-Jurnal Akuntansi, 21(1), 830-859.

Fauzan, F., Ayu, D. A., \& Nurharjanti, N. N. (2019). The Effect of Audit Committee, Leverage, Return on assets, Company Size, and Sales Growth on Tax avoidance. Riset Akuntansi Dan Keuangan Indonesia, 4(3), 171-185. https://doi.org/10.23917/reaksi.v4i3.9338

Handayani, R. (2018). Pengaruh Return on assets (ROA), Leverage dan Ukuran Perusahaan Terhadap Tax avoidance Pada Perusahaan Perbankan yang Listing di BEI Periode Tahun 2012-2015. Jurnal Akuntansi Maranatha, 10(1), 72-84. https://doi.org/10.28932/jam.v10i1.930

Hendrani, A., Uliarta Hasibuan, N., \& Septyanto, D. (2020). The Effect Of The Roa, Audit Committee, and The Company Size on Tax avoidance (Metal and The Like) Listed on Indonesia Stock Exchange (Idx) Period 2014 - 2018. Prosiding ICSMR, $1(1 \quad$ SE-Articles), 85-101. Retrieved from http://conference.loupiasconference.org/index.php/ICSMR/article/view/ 8

Irianto, D. B. S., \& S.Ak, A. W. (2017). The Influence of Profitability, Leverage, Firm Size and Capital Intensity Towards Tax avoidance. International Journal of Accounting and Taxation, 5(2), 33-41. https:// doi.org/10.15640/ijat.v5n2a3

Jensen Michael C., M., \& H., W. (1976). Theory Of The Firm : Managerial Behavior, Agency Cost And Ownership Structure. Human Relations, 72(10), 1671-1696. https://doi.org/10.1177/0018726718812602

Kurniasih, T., \& Ratna Sari, M. (2013). Pengaruh Return on assets, Leverage, Corporate Governance, Ukuran Perusahaan Dan Kompensasi Rugi Fiskal Pada Tax avoidance. Buletin Studi Ekonomi, 18(1), 58-66.

Kusufiyah, yunita Valentina \& Anggraini, D. (2019). Peran Komisaris Independen, Ukuran Perusahaan, Kinerja Keuangan dan Leverage terhadap Usaha Penghindaran Pajak. E-Jurnal Akuntansi, 26, 1601-1631.

Nugrahitha, I. M. A., \& Suprasto, H. B. (2018). Pengaruh Profitabilitas , Leverage , Corporate Governance, dan Karakter Eksekutif pada Tax avoidance. E-Jurnal Akuntansi, 22(36), 2016-2039.

Praditasari, N. K. A., \& Setiawan, P. E. (2017). Pengaruh Good Corporate Governance, Ukuran Perusahaan, Leverage Dan Profitabilitas Pada Tax avoidance. E-Jurnal Akuntansi, 19.2(03), 1229-1258.

Rosa Dewinta, I., \& Ery Setiawan, P. (2016). Pengaruh Ukuran Perusahaan, Umur Perusahaan, Profitabilitas, Leverage, Dan Pertumbuhan Penjualan Terhadap Tax avoidance. E-Jurnal Akuntansi, 14(3), 1584-1615.

Solihin, S., Saptono, S., Yohana, Y., Yanti, D. R., \& Kalbuana, N. (2020). the Influence of Capital Intensity, Firm Size, and Leverage on Tax avoidance on Companies Registered in Jakarta Islamic Index. International Journal of 
Economics, Business and Accounting Research (IJEBAR), 4(03), 272-278. https://doi.org/10.29040/ijebar.v4i03.1330

Tyler, N. J. C. (1986). The relationship between the fat content of Svalbard reindeer in autumn and their death from starvation in winter. Rangifer, 6(2), 311. https://doi.org/10.7557/2.6.2.664

Wijayanti, Yoanis \& Merkusiwati, N. K. L. A. (2017). Pengaruh Proporsi Komisaris Independen, Kepemilikan Institusional, Leverage, Dan Ukuran Perusahaan Pada Penghindaran Pajak. E-Jurnal Akuntansi, 20, 699-728.

Wirawan, H. K., \& Sukartha, I. M. (2018). Pengaruh Kepemilikan Keluarga dan Ukuran Perusahaan pada Agresivitas Pajak dengan Corporate Governancer sebagai Variabel Pemoderasi. E-Jurnal Akuntansi, 23, 595. https://doi.org/10.24843/EJA.2018.v23.i01.p23 